\title{
Echoes of Fairy Tales: Fantasy and Everyday Horror in Guillermo del Toro's Filmography
}

\author{
Gema Navarro Goig and Francisco Javier Sánchez-Verdejo Pérez
}

\begin{abstract}
Guillermo del Toro's filmography uses recurrently old formulas such as archetypal folk and fairy-tale motifs and characters, adapting them to contemporary culture and society. The fantastic acts as a parallel universe to our logical world. His films describe a supernatural reality that intertwines with the ordinary world, using the archetypes of these narrations in the real world. Del Toro claims the figure of the monster as one of his outstanding characters, showing that the classical monsters are usually represented as vulnerable creatures subjected to the brutality of the human being. His films have a utopian spirit, mixed with fairy tales exclusively for adults, morality, goodness or the capacity of sacrifice of his protagonists, the overcoming of obstacles and the deepening of a state of knowledge and virtue. Fantasy serves the director as a vehicle to introduce political and social issues through a series of metaphors, which are appreciable in films such as Pan's Labyrinth, Crimson Peak or The Shape of Water.
\end{abstract}

\section{Keywords}

fairy tales - cinema - fantasy - Gothic - monsters - Guillermo del Toro

\section{$\mathrm{Cr}_{3} \mathrm{~S} \mathrm{~S} \quad 1 \quad$ Introduction}

The rewriting of fairy tales has been reaffirmed in recent decades as a phenomenon that arises without a doubt from the inspiring power of these stories, their complexity and the fascination they arouse. Since the seventies, interpretations of fairy tales in literature, cinematography or art have often experienced a shift toward more critical positions. It is not merely about representing the original stories with images, but about adapting them for an adult audience, but reversing the original meaning through works whose images are loaded with symbolic value. In this sense, a significant part of Guillermo del Toro's 
filmography appropriates images, symbols and structures of the fairy tale, as expressed by himself in an interview in 2017 after a projection of The Shape of Water, in which he described the genres of the movies that he makes as 'fables or fairy tales or parables' (del Toro online). One can preserve the structure of a fairy tale and go on deconstructing the characters or one can try to deconstruct the fairy-tale structure and preserve the simplicity of the characters (Carrasco 17-18). In this director's filmography, one can appreciate that fantasy serves as a vehicle to introduce political and social topics, to elaborate metaphors around fear and hatred and to revalue a series of characters that have suffered rejection or marginalization.

The film Pan's Labyrinth by Guillermo del Toro (2006) can be seen as a paradigm of the adhesion of its director to fairy tales, the Gothic and the fantastic. The fantastic acts as a parallel universe, perceptible by certain characters and by the viewer. Set in Franco's Spain, the protagonist is a girl, Ofelia (Ivana Baquero), who walks into a supernatural and timeless world as an escape from her unbearable reality. This fairy-tale world allows her to develop the courage to face the darkness of her times, and the journey to the underground kingdom becomes a journey towards maturity.

The film draws a parallel between the ordinary world and the supernatural one, reminding us of the codes of Gothic horror films, among other aspects due to the circularity of its narrative or the spatial and magical displacement of the heroine as a figure caught between two realities, between a historical narrative and another fantastic one that can only be explained from the symbolic scope of the fairy tale. At the beginning, when the protagonist lies on the ground, her eyes function as a symbol to express the subjective vision of the character and her own world. Somehow, del Toro associates Ofelia with Snow White, a persecuted heroine who finds refuge with the seven dwarves in the forest (Kérchy 2011; Blair 10). Ironically, del Toro's Snow White will not find refuge in a large country house. Instead of living happily with the seven dwarves as protectors, she will be threatened by the cruel Captain Vidal (Sergi López) and killed by him. However, this first scene reveals that she is alive after her death, and that she will return in another body, in another place and at another time (Zipes "Pan's" 238). At the beginning of the film, and after following a mysterious insect, the girl finds in the forest a stone eye of a small totem, which initiates the protagonist's first contact with the supernatural world. By fitting it into this toem, magic is unleashed at the moment when a fairy disguised as a praying 
mantis appears on the head of the statue. Ofelia sees her and recognizes her as a fairy. She runs after her and discovers the labyrinth of the faun, a messenger of the king of the underworld, who sets forth a series of tests for Ofelia to prove that she is the real princess Moanna, doomed to return to the wonderful underground world. She receives the Book of Crossroads from the faun, whose pages are filled with texts and images, as fantasy and the real world interact.

From that moment on, Ofelia has a double perception that allows her to move between two worlds at the same time, trying to use the symbols and signs of her imaginary space to survive in a social world devoid of dreams and full of ruthless brutality. Tragically, she will not be able to reconcile these two worlds. The journey to the underground kingdom becomes a journey towards maturity and an apprenticeship in which she has to pass a series of tests. In this case, the protagonist's initiation rite towards maturity is loaded with symbols, in which evil manifests itself as a symbolic entity. From the beginning of the film, the dreamlike quality of the adventures experienced by Ofelia is emphasized and the viewer is positioned and codified in a specific genre: the fairy tale for adults. We can see several references to certain fairy tales by the Brothers Grimm, such as 'Hansel and Gretel', or by Perrault, such as 'Little Red Riding Hood', in which innocent children roam in the dark through the woods facing danger. There are also echoes of Alice's Adventures in Wonderland, both in the dress of the protagonist, and in the entrance to the tree, in this case to find the toad, a recurrent animal in many traditional stories. Del Toro calls upon the viewers' prior knowledge of these stories to signify that Ofelia is entering a 'wonderland of her own, albeit much darker and scarier' (Saeger 227).

What good is it to read fairy tales or even view fairy-tale films in times of darkness? [...] del Toro poses in a chilling film that does not mince words nor delude us about the cruelty in our world. Del Toro wants to penetrate the spectacle of society that glorifies and conceals the pathology and corruption of people in power.

ZIPES, "Pan's" 237

There is a series of tests that Ofelia has to overcome, specifically three, a number loaded with symbolism. They will be performed before the next moon by order of the faun. In the first one, she confronts a giant toad from which she has to retrieve a key. In the second, she must open a small door where a dagger is found in the room of the underground kingdom where the pale man lives, a faceless old man who guards a table full of delicacies. Finally, the faun tells her that, in order to access the underground world, Ofelia has to shed innocent 
blood, her young brother's. In the end she will do it with her own blood, to save her brother.

The existence of evil, as an inescapable element in the fairy tale, is present in the figure of Captain Vidal, who represents both the fairy-tale villain and the historical villain: 'a predominant feature of fairy tales is their simplification and their intensification toward the extremes (such as evil) and [...] the fairy tales predilection for cruelty' (Deveny 3). In a metaphorical sense, the watch mechanism that he cleans and cares for obsessively is a projection of how, in his relationships with other characters, he prioritizes control and precision over affective values.

In The Shape of Water (2017), del Toro again contemplates monstrosity as a metaphor or representation of irrational thoughts, pathologies or conflicts repressed by reason; the monstrous element again sets up the question of the nature of evil. In different interviews, del Toro has explained that 'monsters are a religion for me. They're spiritual, they represent many things. And I wanted to tell the story of the patron saint of otherness, of outcasts which was this creature' (Menzel online). Following Gaudette (online), the Amphibian Man is no mere monster but rather 'an elemental river god'. Speaking about the Amphibian Man's aesthetics, Zahed (online) provides Paul Austerberry's explanation: 'I envisioned him emerging from the pool [...] We wanted him to look as if he were emerging in front of the sun figure on this temple'.

This is a film with an impeccable production design in which, besides the idea that the monstrous is necessary and can be beautiful, the 'magical realism' to which the director himself refers stands out (Cooper 26). In this sense, the monster in the movie The Shape of Water is not the reincarnation of evil, it is not a threatening entity, but a vulnerable creature subjected to the brutality of the human being (Solaz online).

The most direct inspiration for this film is Creature from the Black Lagoon, by Jack Arnold (1954), which starts from the tradition of the fantasy genre rooted in ancient myths that narrate the relationship between human and anthropomorphic amphibian creatures. In all honesty, del Toro pays tribute to the film that struck him as a child and achieves a kind of redress after the frustration that the relationship between the anthropomorphic amphibian and the woman was not consummated.

From the literary point of view, the monster is also reminiscent of the aquatic creatures of H. P. Lovecraft's horror stories, specifically from the novella The 
Shadow over Innsmouth (1936). In describing the aquatic beings it seems that we are seeing the creature of The Shape of Water since its shapes were vaguely anthropoid, the head was that of a fish with prodigious bulging eyes, next to the neck they had throbbing gills and in their members they had interdigital membranes. On the other hand, there are many other influences in the film, the result of the director's interest in cinema, such as James Whale's Frankenstein (1931) or Jean Cocteau's Beauty and the Beast (1946).

Del Toro chooses the fable as an effective means of communication with the viewer, told with the cadence of a fairy tale for adults and with an atmosphere that takes us back to the cinema of other times, vindicating the classic tradition of the cinema of monsters. Considering part of Beauty and the Beast as an outstanding influence, here, however, it is the beast who changes the beauty. In a twist to the classic story, it is the heroine who finally saves the monster.

The action takes place in 1962, at the height of the Cuban missile crisis, the greatest period of tension during the Cold War. Given the unmistakable influence of the B-series cinema, there are a series of archetypal characters: the young naive girl, the villain, the scientist, and, of course, the monster. The film combines a spy thriller, a monster story, melodrama, musical nostalgia, action movies and romance between humans and anthropomorphic creatures. All the constants of the director are here: a narrative that develops in a convulsive political period of the recent past-in this case, the Cold War; a creature that suggests that the truly monstrous being is not the one we believe; love as sad; the imaginary as a palliative, reflected in the protagonists' love for movies; a melancholic portrait of homosexuality and the customary bitter racism. It addresses, thus, issues of current relevance, from the imagination and as a political tool.

The characters do not fit completely into the world around them: Elisa (Sally Hawkins) and her friend and neighbour Giles (Richard Jenkins) have a very special bond and complicity; for example, they love the musicals of other times. Elisa is the great protagonist, a fragile character in appearance, but whose convictions are as clear and powerful as her courage when making crucial decisions. Giles, her friend and neighbour, cartoonist and publicist inspired, in some way, by James Whale, the director of the iconic Frankenstein of 1931. Whale was also a painter and illustrator and his homosexuality caused his lack of appreciation in the film industry. For the director, an important moment of the film is when Giles draws with new inspiration when he meets the monster. Colonel Strickland (Michael Shannon), the villain of the movie, is the real monster with a human face, he is in charge of taking the strange creature from the Amazon River (continuing with the homage to Arnold) to the secret scientific-military laboratory in which the story unfolds. There is an element 
that is not expressed as openly in other films: the sexual dimension. This is perhaps the first film in which del Toro delves into love and sex. For the filmmaker, this is important, or at least in this context, and he sees it as a naturalistic, everyday and beautiful element. The non-verbal communication of the woman and the monster propitiate it, they understand each other perfectly and surprisingly in this way.

$\mathrm{C}_{3} 3 . \mathrm{S}_{4}$

CI3.Pi6

Ci3.PI9

\section{$4 \quad$ Crimson Peak and the Tradition of Fairy Tales}

The atmospheric tale of love and death of the film takes place in the decaying mansion known as Crimson Peak, located in northern England. The ancestral home holds a great amount of dark secrets, making sinister actions happen in rapid succession. The house feels like an enchanted castle taken from a fairy tale. The house is really a rotting representation of the family that has inhabited it, a typically Gothic haunted house: it is like a cage, a trap, where characters feel like the insects we see along the film, trapped and about to die of suffocation.

Echoing Gothic classics like Jane Eyre (Charlotte Brontë), Wuthering Heights (Emily Brontë) or Rebecca (Daphne du Maurier), del Toro made Crimson Peak (2015) based on his love of horror, fairy tales and Gothic stories. He wanted to combine and mix these genres. In fact, fairy tales and the Gothic do share many similarities. Inspired by the Brothers Grimm's fairy tales among others (Chávez, 2011), and a fairy tale called 'Bluebeard's Wives', we can find a great tradition leading to Crimson Peak. ${ }^{1}$

Fairy tales, Gothic stories and the horror tradition are three forms of literature that are very closely related. One can read the most horrifying story and yet some elements define it as a fairy tale. Most of the time, the Gothic tale involves romance, meaning not just a love story, but a poetic longing for a past. Horror always has elements different from the other two (Worley 67-80).

Crimson Peak is labelled by critics as a Gothic romance, horror and a Victorian Gothic (Debruge online; Kohn online; Jolin online; Nicholson online). It has also been called a ghost story or a Gothic horror (Schaefer online; ShawWilliams online). Ebiri (online) states upon this complex generic referencing by noting: 'Crimson Peak [...] doesn't always seem to know what it wants to be'.

1 Guillermo del Toro's production presents the love triangle of having two competing wives who cannot coexist in peace. The heroine must act to save her life and preserve her marriage. The husband must choose, being unable to do so, dying in the end. 
Del Toro wanted to make a movie that was a mixture of all these things that he loves.

Guillermo del Toro's ghosts are scary enough to keep the viewer attentive and unquiet. Crimson Peak's ghosts are red like blood and like the red clay the characters' house stands on. Spectres are translucent, confronting the vividly crimson colour. Guillermo del Toro's Crimson Peak provides viewers with an example of tactile contact between humans and ghosts, when, at the beginning of the film, the black hands of a female spectre touch the heroine's shoulder. Borderline horror lies in the idea that to bridge the gap between human and the supernatural it is necessary to endow the dead with properties of living beings (Hearn 237).

Crimson Peak echoes some elements of Pan's Labyrinth, The Shape of Water (and, in some parts, The Devil's Backbone) related to mythology, realism and fantasy. When we read a fairy tale, we as spectators are astonished when facing the beauty of the visuals and the grandness of the scale. In an era where cinema productions are endowed with superheroes, technology, special effects, robots and dinosaurs, it is a great idea to remind ourselves that excitement and entertainment can also be found in a love story full of ghosts, fantasy and fairy-tale elements. Crimson Peak and fairy tales share their imaginative character: they are partly true, and partly pure fantasy. Ghosts are a metaphor for things of the past, a past that reminds us of the time when fairies were part of human lives.

Crimson Peak also bears traces of Charles Perrault's French folktale, 'La Barbe Bleue' (Bluebeard), ${ }^{2}$ namely when Edith is warned by Thomas never to take the mansion's indoor elevator-which leads to its subterranean area-and when Lucille refuses to give her a set of keys to the mansion because some rooms are unsafe. In this film, as in traditional fairy tales, the emphasis lies upon a 'prohibition and its transgression' (Hermansson 3). As in Perrault's folktale, and in traditional tales, Edith's curiosity is too strong; her disobedience, wandering into restricted areas of the mansion, places her in danger. Whereas in a great majority of fairy tales good characters are rewarded, and evil ones are punished, soon showing signs of redemption, Crimson Peak's female characters resemble those of fairy tales, suggesting a resemblance between Victorian angels and monstrous women.

2 For a detailed discussion on how Crimson Peak evokes 'Bluebeard', see Salisbury (2015). 
Guillermo del Toro is one of the contemporary filmmakers who keep going back to fairy-tale stereotypes, relying on hypertextual aesthetics (Kotecki 236). Del Toro resorts to the juxtaposition of real and fantastic worlds to achieve his purpose but, at the same time, constructs an eloquent parallelism between the representation of monstrosity and beauty, a theme that is recurrent in fairy tales.

$\mathrm{C}_{13} . \mathrm{P}_{24}$

He was (and is) the acknowledged master of the ghost story, dealing with a narrative of Gothic Romance that preserves the fairy-tale enchantment. Lucie Armitt (46) argues that fairy tales and the Gothic share the confrontations with the uncanny, and according to Hultgren, del Toro understands his work in relation to the fairy tale indicating that his work mirrors late Victorianism:

It also continues a trend from the Victorian period in which the fairy tale was a genre that united many different kinds of non-realist writing. Del Toro's reliance on the fairy tale genre to describe his films suggests an intellectual debt to the Victorian period, as well as a fascination with enduring stories and the preservation of a great variety of popular past art forms and narratives. $\left(155^{-15^{6}}\right)$

Atmosphere, settings and characters, everything feels really intense. Ultimately what Guillermo del Toro does with his stories is show that humans are far more terrible creatures than restless spirits, not very far from fairy tales.

\section{Works Cited}

Armitt, Lucie. Theorizing the Fantastic. London: Arnold, 1996.

Blair, L. N. 'Pan's Labyrinth: Finding the Center'. Presented at the National Conference of the Popular Culture Association, New Orleans, LA, USA. 2009.

Carrasco, Cristina, 'Contestatory Fairy Tales and Liminal Spaces in Guillermo del Toro's Pan's Labyrinth', Revista de Humanidades. Tecnológico de Monterrey, 31-32 (2001): 13-3o.

Chávez, Daniel. 'De faunos hispánicos y monstruos en inglés, la imaginación orgánica de Guillermo del Toro'. Tendencias del cine iberoamericano en el nuevo milenio: Argentina, Brasil, España y México, Juan Carlos Vargas (ed.). Guadalajara: Universidad de Guadalajara, 2011. 373-410. 
Cooper, Rand Richards. 'Monsters, Politics, Romance. "The Shape of Water". Commonweal 23rd February 2018, https://www.commonwealmagazine.org/monsterspolitics-romance.

Debruge, Peter. 'Film Review: "Crimson Peak" . Variety 13th October 2015, http://variety. com/2015/film/reviews/crimson-peak-film-review-1201613988/.

Del Toro, Guillermo. 'The Shape of Water Q\&A with Guillermo del Toro and Vanessa Taylor'. Directors Guild of America 2017, https://www.youtube.com/watch?v=04WoojFSejU.

Deveny, Thomas, 'Once upon a Time in Spain in 1944: The morphology of El Laberinto del Fauno', Journal of Interdisciplinaries studies on film in Spanish 1.1 (2008): 1-12.

Ebiri, Bilge. 'Crimson Peak Looks so Good that You Might not Notice its Half-Baked Story'. Vulture 16th October 2015, http://www.vulture.com/2015/10/movie-reviewcrimson-peak.html.

Gaudette, Emily. 'Shape of Water Guillermo del Toro Reflects on Sex, Monsters and Catholic Saints'. Newsweek 1st December 2017, http://www.newsweek.com/2017/12/ 15/guillermo-del-toro-shape-water-sex-catholicism-727518.html.

Hearn, Lafcadio. 'Nightmare Touch'. Shadowings. New York: Cosimo, 2007.

Hermansson, Casie E. Bluebeard. A Reader's Guide to the English Tradition. Jackson: UP of Mississippi, 2009 .

Hultgren, Neil, 'The Museum that Looks Back: Guillermo del Toro: At Home with Monsters'. Neo-Victorian Studies 10.1 (2017): 152-181.

Jolin, Dan. 'Crimson Peak Review'. Empire 15th October 2015, http://www.empireonline. com/movies/crimson-peak-2/review/.

Kérchy, Anna (ed.). Postmodern Reinterpretations of Fairy Tales. Lewiston, Lampeter: The Edwin Mellen Press, 2011.

Kohn, Eric. 'Review: Why Guillermo del Toro's Crimson Peak is not your Average Gothic Romance'. Indiewire 14th October 2015, http://www.indiewire.com/2015/10/reviewwhy-guillermo-del-toros-crimson-peak-is-not-your-average-gothic-romance$56645 /$.

Kotecki, Kristine. 'Approximating the Hypertextual, Replicating the Metafic-tional:Textual and Sociopolitical Authority in Guillermo del Toro's Pan's Labyrinth'. Marvels \& Tales:Journal of Fairy-Tale Studies 24.2 (2010): 235-254.

Menzel, S. 'The Shape of Water Telluride Q\&A featuring Guillermo del Toro'. 5th September 2017, https://youtu.be/bh2B6kDYVLo.

Nicholson, Amy. 'Guillermo del Toro's Deliriously Artificial Crimson Peak is a Faithful Homage to a Foolish Genre'. LA Weekly 14th October 2015, http://www.laweekly.com/film/guillermo-del-toros-deliriously-artificial-crimson-peak-is-a-faithfulhomage-to-a-foolish-genre-6164642. 
Saeger, J. M. The Recuperation of Historic Memory: Recognizing Suppressed Female Voices From the Spanish Civil War and Francoist Repression. University of California: California Digital Library, 20o9.

Salisbury, Mark. Crimson Peak: The Art of Darkness. London: Titan Books, 2015.

Schaefer, Sandy. 'Guillermo del Toro to Direct Crimson Peak; Could 'Mountains of Madness' Happen?', Screen Rant 4th December 2012, http://screenrant.com/guillermodel-toro-crimson-peak-mountains-madness.

Shaw-Williams, Hannah. 'Guillermo Del Toro Says Crimson Peak is Shocking, Kinky, Gothic \& Scary', Screen Rant 1st July 2013, http://screenrant.com/guillermo-deltoro-crimson-peak-movie-details/.

Solaz, Lucía. 'Monstruos y demás parientes'. Encadena2. Revista de cine May 2009, http://www.encadenados.org/nou/n-61-el-mal-en-el-cine/monstruos-y-demasparientes.

Worley, L. 'The Horror! Gothic Horror Literature and Fairy Tales: The Case of «Der Räuberbräutigam»'. Colloquia Germanica 42(1) (2009): 67-80.

Zahed, Ramin. 'Strong color pallette brings a long-held vision of "Shape of Water" to life'. Los Angeles Times 25th January 2018, http://www.latimes.com/entertainment/ envelope/la-en-mn-crafts-shape-water-design-20180125-story.html.

Zipes, Jack. 'Pan's Labyrinth'. Journal of American Folklore 121.480 (January 2008): 236240. 